\title{
Lung function and bronchial responsiveness measured by forced oscillometry after bronchopulmonary dysplasia
}

\author{
E J DUIVERMAN, ${ }^{*}$ J A DEN BOER, ${ }^{*}$ R J ROORDA, * C M H M ROOYACKERS, $\dagger$ M VALSTAR, $\dagger$ \\ AND K F KERREBIJN $\dagger$ \\ * Department of Paediatrics, Subdivision of Respiratory Diseases, Juliana Children's Hospital, The Hague, \\ and tDepartment of Paediatrics, Subdivision of Respiratory Diseases, Erasmus University, University \\ Hospital Rotterdam, and Sophia Children's Hospital, Rotterdam, The Netherlands
}

SUMmARY Forced oscillometry was used to investigate whether lung injury due to bronchopulmonary dysplasia in eary life caused abnormalities in bronchial calibre or an increase in bronchial responsiveness to histamine at school age. Results were compared with data obtained from healthy children born prematurely and from healthy children born at term. There was a mild increase in frequency dependence of total respiratory resistance in children who suffered from lung injury in early life, which indicates uneven ventilation in peripheral airways. Bronchial responsiveness to histamine in these subjects was normal. No abnormalities were found in the control group.

We conclude that lung injury in early life may cause residual abnormalities of peripheral airways. This does not happen in premature babies who do not have respiratory problems in the neonatal period.

Pulmonary injury during the first years of life when the lungs are growing rapidly, 12 can induce bronchiolar lesions that may interfere with alveolar and vascular growth. ${ }^{34}$ Some investigators have found a high incidence of long term pulmonary sequelae in premature babies with idiopathic respiratory distress syndrome,${ }^{5-8}$ whereas others have found few residual pulmonary abnormalities. ${ }^{9-15}$

In this study we looked for indicators of long term airway damage - that is, abnormal respiratory resistance and frequency dependence of resistance-and for bronchial hyper-responsiveness to histamine in 15 children who had idiopathic respiratory distress syndrome with bronchopulmonary dysplasia as neonates, and in 15 children who were born prematurely but did not have idiopathic respiratory distress syndrome.

\section{Subjects and methods}

We investigated two groups. Group 1 comprised 15 children aged $3 \cdot 3$ to $10 \cdot 6$ years (mean $6 \cdot 3$ ) who were born prematurely at gestational ages of 26 to 34 weeks (mean 28.1) and had idiopathic respiratory distress syndrome. They were mechanically ventilated with moderate to high oxygen mixtures for one to 46 days (mean 21.9 days) and developed severe bronchopulmonary dysplasia diagnosed by radiological ${ }^{16}$ and clinical ${ }^{17}$ criteria (table 1$)$. Group 2 comprised 15 children aged 3.8 to 8.0 years (mean 5.9) who were born at gestational ages of 30 to 35 weeks (mean 31.9). None had important respiratory symptoms during the neonatal period or in later life (table 2).

According to their parents none of the children had upper or lower respiratory tract symptoms during the two weeks before the study. A history of current and past respiratory symptoms (for example, recurrent episodes of cough and wheezing) and a family history of asthma or hay fever in first and second degree relatives was taken by an interviewer (ED) who completed a questionnaire. ${ }^{18}$

As many children in this study were less than 5 years of age lung function was measured by the forced oscillation technique. ${ }^{19}$ A pseudorandom noise pressure signal containing all harmonics of $2-26 \mathrm{~Hz}$ is applied to the mouth with a loudspeaker. Mouth pressure and flow signals recorded by two 
identical differential transducers (Validine MP445) are fed into a Fourier analyser, which averages these values over a time interval of 16 seconds and calculates the impedance of the respiratory system at $2,4,6,8,10,12,14,16,18,20,22,24$, and $26 \mathrm{~Hz}$. Forced oscillation is a convenient method for children from about $2 \frac{1}{2}$ years of age onwards because only passive cooperation is needed. During measurements the child is seated and the apparatus is connected with a mouth piece. The nose is clipped and the floor of the mouth and cheeks are supported to eliminate shunting of airflow to the upper airways. With forced oscillation total respiratory resistance $\left(\mathrm{R}_{\mathrm{rs}}\right)$ in $\mathrm{cm} \mathrm{H}_{2} \mathrm{O} / \mathrm{l} / \mathrm{second}$ and reactance are measured simultaneously over the frequency range of $2-26 \mathrm{~Hz}$. $R_{r s}$ is determined mainly by the patency of the central airways, and is dependent to only a limited degree on the resistance of the lungs and chest wall. ${ }^{20}$ Because $R_{r s}$ is measured over a frequency spectrum, the frequency dependence of $R_{\mathrm{rs}}\left(\overline{\mathrm{dR}_{\mathrm{rs}} / \mathrm{df}}\right)$ in $\mathrm{cm} \mathrm{H}_{2} \mathrm{O} / \mathrm{l} /$ second $^{2}$ can also be calculated. ${ }^{21} 22 \overline{\mathrm{dR}_{\mathrm{rs}} / \mathrm{df}}$ is a measure of unevenness of ventilation, and is determined by the patency of the peripheral airways. Using the forced oscillation technique, we selected the resistance of the respiratory system at an oscillation frequency of $6 \mathrm{~Hz}\left(\mathrm{R}_{\mathrm{rs} 6}\right)$ as a measure of the patency of the central airways, and $\overline{\mathrm{dR}_{\mathrm{rs}} / \mathrm{df}}$ as a measure of the calibre of the peripheral airways. $R_{r s 6}$ was chosen because an oscillation frequency of $6 \mathrm{~Hz}$ was the lowest frequency with a favourable signal:noise ratio. ${ }^{20}$ All children had a physical examination before the measurements.

Bronchial responsiveness was measured by a histamine challenge test. Histamine was administered through a Rosenthal-French dosimeter connected to a DeVilbiss nebuliser (type 646). The dosimeter was operated by compressed air at 20 psi with a timing adjustment of 0.6 seconds. Doses of histamine biphosphate in saline of $2 \cdot 5,5,10,20,40$, 80,160 , and $320 \mu \mathrm{g}$ were given, each in four inhalations of $5 \mu \mathrm{l}$ at five minute intervals. Saline was inhaled before histamine to exclude non-specific responses. Each challenge was preceded by five consecutive forced oscillation measurements from which the mean baseline value was calculated. The mean of three technically satisfactory forced oscillation measurements was used to construct a dose response curve. $\mathrm{PD}_{40} \mathrm{R}_{\mathrm{rs6}}$, defined as the dose of histamine that caused a $40 \%$ increase from the mean baseline $R_{r s 6}$, was calculated from the dose response curve by linear interpolation of data points. We have previously shown that $P_{40} R_{r s 6}$ is closely correlated with the dose of histamine that caused a $20 \%$ increase in forced expiratory volume in one second $\left(\mathrm{PD}_{20} \mathrm{FEV}_{1}\right){ }^{23}$ Bronchial challenge was stopped after inhalation of $320 \mu \mathrm{g}$ histamine or after $\mathrm{PD}_{40} \mathrm{R}_{\mathrm{rs} 6}$ had been obtained.

Mean predicted baseline values of $R_{r s 6}$ and $\overline{\mathrm{dR}_{\mathrm{rs}} / \mathrm{df}}$ were taken from a reference population with no past or current history of pulmonary injury, asthma, or other recurrent respiratory disease. ${ }^{19}$ Forced oscillation and bronchial responsiveness values were expressed as standard scores, calculated from the formula:mean measured value - mean predicted value $\div$ by the standard deviation of the mean predicted value. Baseline $R_{r s 6}$ was considered increased if it was higher than +1.65 standard scores and $\overline{\mathrm{dR}_{\mathrm{rs}} \mathrm{df}}$ decreased if it was lower than -1.65 standard scores $(95 \%$ confidence intervals from the predicted mean). Bronchial responsiveness was considered increased if $P D_{40} R_{r s 6}$ was lower than -1.65 standard scores from bronchial responsiveness measured by forced oscillation in a reference population of healthy children born at term aged 5-8 years (that is reacting to less than $300 \mu \mathrm{g}$ histamine). ${ }^{24}$

For ethical reasons we were not allowed to perform skin prick tests or sample blood gases but written informed consent was obtained from the parents. Wilcoxon's two sample test was used to analyse the significance of differences between the groups for baseline values and $\mathrm{PD}_{40} \mathrm{R}_{\mathrm{rs}}$ histamine. A $p$ value of $<0.05$ was considered significant.

\section{Results}

Six of the children who had bronchopulmonary dysplasia had persistent symptoms at the time of investigation; one (case 6 ) had symptoms induced by exercise. Two had symptoms that disappeared after the age of 4 (cases 7 and 8). Seven children never had symptoms after their discharge from hospital (table 1). There was no difference in the mean age at the time of investigation between children with and without symptoms. None of the children who had not had idiopathic respiratory distress syndrome had a history of past or current respiratory symptoms (table 2). Three children who had bronchopulmonary dysplasia $(20 \%)$ and three children who had not had idiopathic respiratory distress syndrome $(20 \%)$ had a first or second degree relative with asthma or hay fever.

Of the six children who had bronchopulmonary dysplasia with current symptoms $R_{r s 6}$ was increased in three. Decreased $\overline{\mathrm{dR}_{\mathrm{rs}} / \mathrm{df}}$ values were found in four. Of the nine children without current symptoms, $R_{r s o}$ was increased in one and $\overline{\mathrm{dR}_{\mathrm{rs}} / \mathrm{df}}$ was decreased in two (figure, table 1). In all children who had not had idiopathic respiratory distress syndrome, $R_{r s o}$ values were within the normal range. $\overline{\mathrm{dR}_{\mathrm{rs}} / \mathrm{df}}$ was decreased in one (figure, table 2). 
Table 1 Children who had had bronchopulmonary dysplasia

\begin{tabular}{|c|c|c|c|c|c|c|c|c|c|}
\hline \multirow[t]{2}{*}{ Case No } & \multirow{2}{*}{$\begin{array}{l}\text { Age at } \\
\text { investi- } \\
\text { gation } \\
\text { (years) }\end{array}$} & \multirow{2}{*}{$\begin{array}{l}\text { First or } \\
\text { second } \\
\text { degree } \\
\text { relative } \\
\text { with asthma }\end{array}$} & \multirow{2}{*}{$\begin{array}{l}\text { Gestational } \\
\text { age (weeks) }\end{array}$} & \multicolumn{2}{|l|}{ Scores: } & \multicolumn{2}{|c|}{ Standard scores } & \multicolumn{2}{|l|}{$P D_{40} R_{r s t}$} \\
\hline & & & & $\begin{array}{l}\text { Northway } \\
\text { et } a^{16}\end{array}$ & $\begin{array}{l}\text { Toce } \\
\text { et } \text { al }^{17}\end{array}$ & $R_{r s o}$ & $\overline{d R_{r s} / d f}$ & $\begin{array}{l}\text { Dose of } \\
\text { histamine } \\
(\mu g)\end{array}$ & $\begin{array}{l}\text { Standard } \\
\text { score }\end{array}$ \\
\hline \multicolumn{10}{|c|}{$\begin{array}{l}\text { With current } \\
\text { respiratory symptoms: }\end{array}$} \\
\hline 2 & $6 \cdot 1$ & No & 29 & 4 & 20 & -0.64 & $-1 \cdot 17$ & 100 & -3.58 \\
\hline 3 & $5 \cdot 0$ & No & 28 & 4 & 20 & 0.96 & -0.50 & $>320$ & \\
\hline 4 & $6 \cdot 8$ & No & 29 & 4 & 20 & 0.87 & $-3 \cdot 50$ & $>320$ & \\
\hline 5 & $4 \cdot 4$ & No & 27 & 3 & 20 & $1 \cdot 84$ & $-4 \cdot 00$ & $>320$ & \\
\hline 6 & $7 \cdot 0$ & Yes & 32 & 3 & 10 & $1 \cdot 74$ & $-3 \cdot 50$ & $>320$ & \\
\hline \multicolumn{10}{|c|}{$\begin{array}{l}\text { With past, but not } \\
\text { current respiratory } \\
\text { symptoms: }\end{array}$} \\
\hline 8 & $9 \cdot 2$ & Yes & 29 & 4 & 25 & 0.28 & $-1 \cdot 50$ & 290 & $-1 \cdot 76$ \\
\hline \multicolumn{10}{|c|}{$\begin{array}{l}\text { With no respiratory } \\
\text { symptoms: }\end{array}$} \\
\hline 9 & $6 \cdot 2$ & No & 34 & 3 & 12 & $1 \cdot 19$ & $-2 \cdot 17$ & 180 & $-2 \cdot 56$ \\
\hline 10 & $5 \cdot 5$ & No & 32 & 3 & 19 & $0 \cdot 31$ & $-1 \cdot 50$ & $>320$ & \\
\hline 11 & $10 \cdot 0$ & Yes & 32 & 3 & 3 & -0.28 & 0.67 & $>320$ & \\
\hline 12 & $3 \cdot 3$ & No & 28 & 3 & 15 & $1 \cdot 11$ & -0.33 & 240 & $-2 \cdot 08$ \\
\hline 13 & $7 \cdot 2$ & No & 29 & 2 & 20 & -0.19 & -0.67 & $>320$ & \\
\hline 14 & $5 \cdot 9$ & No & 26 & 3 & 5 & 1.96 & $-1 \cdot 33$ & $>320$ & \\
\hline 15 & $4 \cdot 4$ & No & 28 & 1 & 10 & $0 \cdot 16$ & -1.83 & $>320$ & \\
\hline
\end{tabular}

Table 2 Children born prematurely without idiopathic respiratory distress syndrome

\begin{tabular}{|c|c|c|c|c|c|c|c|}
\hline \multirow[t]{2}{*}{ Case No } & \multirow{2}{*}{$\begin{array}{l}\text { Age at } \\
\text { investigation } \\
\text { (years) }\end{array}$} & \multirow{2}{*}{$\begin{array}{l}\text { First or } \\
\text { second } \\
\text { degree } \\
\text { relative } \\
\text { with asthma }\end{array}$} & \multirow{2}{*}{$\begin{array}{l}\text { Gestational } \\
\text { age (weeks) }\end{array}$} & \multicolumn{2}{|c|}{ Standard scores } & \multicolumn{2}{|l|}{$P D_{40} R_{r s n}$} \\
\hline & & & & $R_{r \mathrm{rn}}$ & $\overline{d R_{r s} / d f}$ & $\begin{array}{l}\text { Dose of } \\
\text { histamine } \\
(\mu g)\end{array}$ & $\begin{array}{l}\text { Standard } \\
\text { scores }\end{array}$ \\
\hline 16 & $7 \cdot 3$ & No & 35 & $0 \cdot 80$ & -0.23 & $>320$ & \\
\hline 17 & $8 \cdot 0$ & No & 34 & 0.92 & -0.83 & $>320$ & \\
\hline 19 & $4 \cdot 2$ & No & 32 & $0 \cdot 82$ & $3 \cdot 63$ & $>320$ & \\
\hline 20 & 6.8 & Yes & 31 & $-1 \cdot 01$ & $1 \cdot 36$ & 220 & $-2 \cdot 22$ \\
\hline 21 & $6 \cdot 8$ & Yes & 31 & $-1 \cdot 16$ & 0.88 & $>320$ & \\
\hline 22 & $5 \cdot 5$ & No & 32 & $0 \cdot 02$ & $0 \cdot 16$ & $>320$ & \\
\hline 23 & $5 \cdot 4$ & No & 32 & 0.19 & 0.50 & $>320$ & \\
\hline 24 & $6 \cdot 7$ & No & 32 & 0.19 & 0.50 & $>320$ & \\
\hline 25 & $6 \cdot 6$ & No & 31 & $1 \cdot 09$ & $3 \cdot 18$ & $>320$ & \\
\hline 26 & $3 \cdot 8$ & No & 32 & $0 \cdot 10$ & $0 \cdot 07$ & 200 & $-2 \cdot 38$ \\
\hline 28 & 3.8 & No & 31 & $-1 \cdot 22$ & $3 \cdot 33$ & $>320$ & \\
\hline 29 & $7 \cdot 0$ & No & 30 & -1.85 & 3.83 & $>320$ & \\
\hline 30 & $4 \cdot 3$ & Yes & 33 & 0.98 & $-2 \cdot 17$ & $>320$ & \\
\hline
\end{tabular}

The mean $R_{r s s}$ was significantly higher in the children who had bronchopulmonary dysplasia with current respiratory symptoms than in the children who had not had idiopathic respiratory distress syndrome $(p<0.05)$. The differences between the children who had had bronchopulmonary dysplasia with and without current symptoms was not significant. The mean $\overline{\mathrm{dR}_{\mathrm{rs}} / \mathrm{df}}$ was significantly lower in the children who had bronchopulmonary dysplasia with current symptoms than in those without $(p<0 \cdot 01)$. Both groups had a significantly lower mean $\overline{\mathrm{dR}_{\mathrm{rs}} / \mathrm{df}}$ than the children who did not have idiopathic respiratory distress syndrome $(p<0 \cdot 01)$.

Of the children who had bronchopulmonary dysplasia, moderate bronchial hyper-responsiveness was found in one of six with current symptoms and 

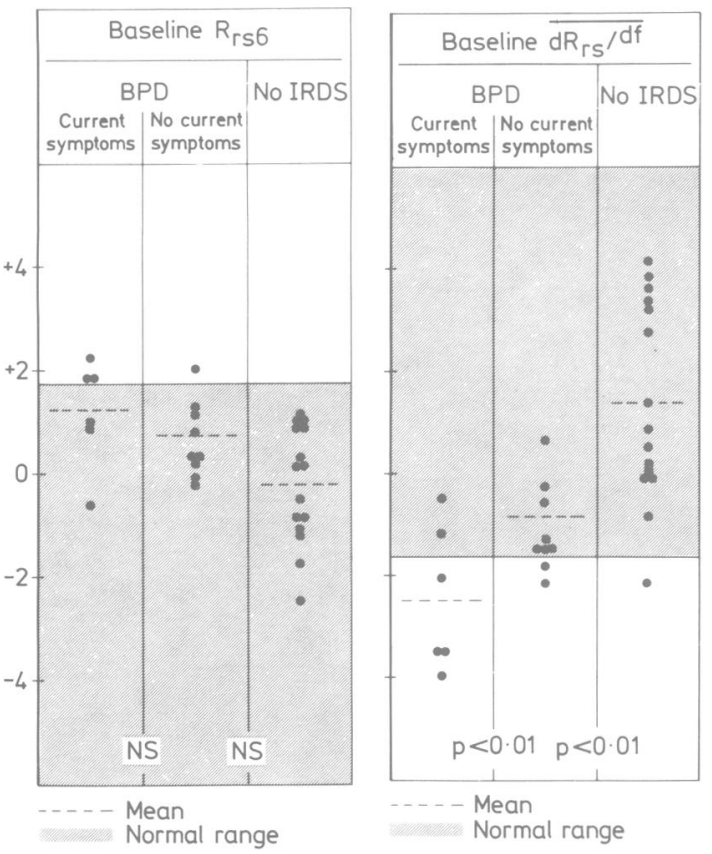

Figure Children who were born prematurely and had bronchopulmonary dysplasia compared with healthy children born prematurely who did not have idiopathic respiratory distress syndrome.

in one child who had had symptoms in the past (table 1). Bronchial hyper-responsiveness was present in two children who never had noticeable respiratory symptoms after discharge from hospital. Moderate bronchial hyper-responsiveness was found in three children who had not had idiopathic respiratory distress syndrome (table 2).

There was no significant difference in mean $P D_{40} R_{r s 6}$ to histamine between the children who had bronchopulmonary dysplasia and the subjects who had not had idiopathic respiratory distress syndrome, or between these two groups and the reference population.

\section{Discussion}

Severe lung injury during early life may affect the growth and development of the respiratory system. ${ }^{3+}$ Injury to immature lung structures may cause subsequent damage of peripheral airways. ${ }^{+}$ Important long term abnormalities that have been described in children who had been ventilated for idiopathic respiratory distress syndrome are airway obstruction-that is increased airway resistance, diminished dynamic lung volume and expiratory flow, increased residual volume, as well as bronchial hyper-responsiveness to histamine, methacholine, or exercise. ${ }^{5-8}$ These studies also reported a higher incidence of dysfunction when idiopathic respiratory distress syndrome had been complicated by bronchopulmonary dysplasia. In children with asthma, both airway obstruction and bronchial hyperresponsiveness are independent indicators of chronic lung disease. ${ }^{25}$ Our purpose was to investigate the incidence of these indicators in children who had had idiopathic respiratory distress syndrome with bronchopulmonary dysplasia. We therefore compared children of school age who were born prematurely and had idiopathic respiratory distress syndrome with severe bronchopulmonary dysplasia, with children born prematurely who had not had idiopathic respiratory distress syndrome.

We have used forced oscillation to distinguish between central and peripheral airway obstruction. Forced oscillation measurements can be obtained in children from about $2 \frac{1}{2}$ years of age because only passive cooperation is needed. The within subject reproducibility of consecutive forced oscillation measurements is similar to that of forced expiratory flow volume curves. ${ }^{23}$ Forced oscillation appears to be as sensitive in measuring bronchial hyperresponsiveness as $F E V_{1} \cdot{ }^{23}$ The results of forced oscillation testing showed that central and peripheral airway function were abnormal in most children with current symptoms. Of the children who were free of symptoms, however, one had abnormal measurements.

Many children who had no respiratory symptoms after having had bronchopulmonary dysplasia had values of $\overline{\mathrm{dR}_{\mathrm{r}} / \mathrm{df}}$ that were at the lower limit of the normal range. This resulted in a significantly lower mean $\overline{\mathrm{dR}_{\mathrm{rs}} \mathrm{df}}$ than in the healthy controls born at term from the reference population ${ }^{19}$ and in children who were born prematurely but did not have idiopathic respiratory distress syndrome. This suggests that idiopathic respiratory distress syndrome and bronchopulmonary dysplasia may have caused subtle damage to peripheral airways that has not been shown by previous studies.

Premature birth not followed by idiopathic respiratory distress syndrome did not result in abnormal lung function according to the indicators used in this study. Although the premature babies who did not develop idiopathic respiratory distress syndrome were on average four weeks more mature at birth than those with idiopathic respiratory distress syndrome, it seems unlikely that this difference has influenced our results.

Our findings about central airway function are in agreement with those in most other studies. ${ }^{9-15}$ Peripheral airway function has not to our knowledge been assessed. 
There was no difference in the incidence of bronchial hyper-responsiveness between children who had bronchopulmonary dysplasia, irrespective of current symptoms, and children born prematurely who had not had idiopathic respiratory distress syndrome. Our results are therefore different from those of Smyth et al, ${ }^{5}$ Bertrand et al, ${ }^{6}$ and Wheeler et $a l,{ }^{7}$ all of whom found a high incidence of slight to moderate bronchial hyper-responsiveness after idiopathic respiratory distress syndrome or bronchopulmonary dysplasia. Our findings indicate that prematurity or severe lung injury in early life do not lead to the degree of bronchial hyper-responsiveness that is commonly seen in children with asthma. ${ }^{24}$ Todisco et al found that the responsiveness to methacholine in premature infants and in survivors of idiopathic respiratory distress syndrome was within the normal range by school age. ${ }^{26}$ It is not clear why some children in this study had bronchial hyper-responsiveness. There was no association with a family history of asthma in first or second degree relatives, nor with baseline airway calibre, though bronchial hyper-responsiveness has been associated with atopy. ${ }^{27}$ We were unable to study atopy, but because three of the four children with bronchial hyper-responsiveness had no current symptoms atopy seems unlikely.

Viral infections may also cause transient bronchial hyper-responsiveness. ${ }^{28}$ Although we tried to exclude patients who had had viral respiratory infections in the two weeks preceding the measurements, we cannot be sure that some of the hyper-responsive children may have had slight infections that were not noticed and induced transient bronchial hyperresponsiveness.

We conclude that about $40 \%$ of the children who had survived idiopathic respiratory distress syndrome with severe bronchopulmonary dysplasia had current respiratory symptoms into school age. Most subjects who continued to have symptoms after idiopathic respiratory distress syndrome and bronchopulmonary dysplasia had increased $R_{r s t}$ or decreased $\overline{\mathrm{dR}_{\mathrm{rs}} / \mathrm{df}}$, indicating obstruction in different parts of the airway. Although central and peripheral airway calibre in most asymptomatic children who had bronchopulmonary dysplasia was within the normal range, low $\overline{\mathrm{dR}_{\mathrm{rs}} / \mathrm{df}}$ values suggest subtle peripheral airway damage. Whether this will result in airway disease in future is uncertain. Premature birth without idiopathic respiratory distress syndrome did not result in abnormal values of $R_{r s}$ or $\overline{\mathrm{dR}_{\mathrm{rs}} / \mathrm{df}}$. It is therefore unlikely that immaturity of the respiratory system without injury will lead to abnormal development of the airways. Our data do not allow us to differentiate between bronchopulmonary dysplasia and uncomplicated idiopathic respiratory distress syndrome as causes of airway damage because only children who suffered from bronchopulmonary dysplasia were included in the study. In the light of the findings in prematurely born children who did not develop idiopathic respiratory distress syndrome, however, we speculate that the severity of lung injury is an important determinant of the risk of long term airway damage. We also conclude that bronchial hyper-responsiveness was not a feature of children with idiopathic respiratory distress syndrome and bronchopulmonary dysplasia.

Whether treatment of respiratory symptoms in children who had severe neonatal lung damage will have an effect on airway function later in life is unknown. In view of our findings and those of others, it can be speculated that such treatment should be recommended.

We thank Dr J van der Laag and Dr BP Cats (Wilhelmina Children's Hospital. Utrecht) for allowing us to study children treated for bronchopulmonary dysplasia in their hospital, Marike van Groen for secretarial help, and Professor $R$ van Strik for statistical advice. The study was partly funded by the Dutch Asthma Foundation (project 82.19).

\section{References}

Cudmore RE. Emery JL. Mithal A. Postnatal growth of bronchi and bronchioles. Arch Dis (hild 1962:37:481-2.

- Hogg JC, Williams J, Richardson JB, Macklem PT. Thurlbeck WM. Age as a factor in the distribution of lower airway conductance and in the pathologic anatomy of obstructive lung discase. $N$ Engl J Med 197();282:1283-7.

Thurlbeck WM. Growth. development and ageing of the lung. In: Scadding JG. Cumming G. Thurlbeck WM. eds. Scientific foundations of respiratory medicine. 1st ed. London: Heinemann. 1982:91-110.

+ Chancy HR. Mallory GB. Motoyama EK. Mutich RL. Functional development of the lung in infants with severe bronchopulmonary dysplasia. Am Rev Respir Dis 1987:135:A126.

Smyth JA. Tabachnik ET. Duncan WJ. Reilly BJ. Levison II. Pulmonary function and bronchial hyperreactivity in long-term survivors of bronchopulmonary dysplasia. Pediatrics 1981:68: 336-40.

- Bertrand JM. Riley S. Popkin J, Coates AL. The long-term pulmonary sequelac of prematurity: the role of familial airway hyperreactivity and the respiratory distress syndrome. $N$ Engl Med 1985:312:742-5.

Whecler WB. Castile RG. Brown ER. Wohl MEB. Pulmonary function in survivors of prematurity. Am Rev Respir Dis 1984:129:A218

* Bader D, Ramos AD. Lew CD, Platzker ACG, Stabile MW. Keens TG. Childhood sequelac of infant lung disease: exercise and pulmonary function abnormalities after bronchopulmonary dysplasia. J Pediatr 1987:110:693-9.

"Lamarre A. Linsae L, Reilly B.J. Swyer PR. Levison H. Residual pulmonary abnormalities in survivors of idiopathic respiratory distress syndrome. Am Rev Respir Dis 1973;108: $56-61$.

11 Coates AL. Bergsteinsson H. Desmond K. Outerbridge EW. Beaudry PH. Long-term pulmonary sequelac of premature birth with and without idiopathic respiratory distress syndrome. J Pediatr 1977:90:611-6.

$"$ Heldt GP. Melllroy MB. Hansen TN. Tooley WH. Exercise 
performance of the survivors of hyaline membrane disease. J Pediatr 1980;96:995-9.

12 Borkenstein J, Borkenstein M. Rosegger H. Pulmonary function studies in longterm survivors with artificial ventilation in the neonatal period. Acta Paediatr Scand 1980;69:159-63.

1.3 Stahlman M, Hedvall G. Lindstrom D, Snell J. Role of hyaline membrane disease in production of later childhood lung abnormalitics. Pediatrics 1982;69:572-6.

14 Mansell AL, Driscoll JM, James LS. Pulmonary follow-up of moderately low birth weight infants with and without respiratory distress syndrome. Am Rev Respir Dis 1985;131:A249.

15 Biscoll DJ, Kleinberg F. Heise CT, Staats BA. Cardiorespiratory function in asymptomatic survivors of neonatal respiratory distress syndrome. Mayo Clin Proc 1987:62:695-70).

${ }^{16}$ Northway WH. Rosan RC, Porter DY. Pulmonary disease following respiratory therapy of the hyaline-membrane disease; bronchopulmonary dysplasia. $N$ Engl J Med 1967;276:357-68.

17 Toce SS, Farrell PM, Lewitt LA, Samuels DP, Edwards DK. Clinical and roentgenological scoring systems for assessing bronchopulmonary dysplasia. Am J Dis Child 1984:138:581-5.

is Kerrebijn KF, Hoogeveen-Schroot HCA, van der Wall MC. Chronic nonspecific respiratory disease in children, a five year follow-up study. Acta Paediatr Scand 1977;261:1-72.

19 Duiverman EJ, Clement J, van de Woestijne KP. Neijens HJ, van den Bergh ACM. Kerrebijn KF. Forced oscillation technique; reference values for resistance and reactance over a frequency spectrum of 2-26 Hz in healthy children aged 2.3-12.5 years. Bull Europ Physioputhol Respir 1985;21:171-8.

20 Clément J, Lándsèr FJ, van de Woestijne KP. Total resistance and reactance in patients with respiratory complaints with and without airways obstruction. Chest 1983;83:215-20.
21 Mead J. Contribution of compliance of airways to frequency dependent behaviour of lungs. J Appl Physiol 1969;26:67(1-3.

22 Harf A. Decremer M. Zin W. Milic-Emili J. Chang HK. Respiratory resistance in dogs by the single-breath and forced oscillation methods. J Appl Physiol 1985:59:262-5.

23 Duiverman EJ. Neijens HJ, van der Snee-van Smaalen M. Kerrebijn KF. Comparison of forced oscillometry and forced expirations for measuring dose-related responses to inhaled methacholine in asthmatic children. Bull Europ Physiopathol Respir 1986:22:433-6.

${ }^{24}$ Duiverman EJ. Neijens HJ, van Strik R. Affourtit MJ, Kerrebijn KF. Lung function and bronchial responsiveness in children who had infantile bronchiolitis. Pediatr Pulmonol 1987:3:38-44.

25 Martin AJ, Landau LI, Phelan PD. Lung function in young adults who had asthma in childhood. Am Rev Respir Dis 1980;122:609-15.

26 Todisco T. Dottorini M. Outcome for survivors from respiratory distress syndrome. Lancet 1987:i:1213.

${ }^{27}$ Neijens HJ, Duiverman EJ, Kerrebijn KF. Bronchial responsiveness in children. Pediatr Clin North Am 1983:30:829-46.

${ }^{28}$ Empey DW, Laitinen LA, Jacobs L. Gold WM. Nadel JA. Mechanics of bronchial hyperreactivity in normal subjects after upper respiratory tract infection. Am Rev Respir Dis 1976:113:131-9.

Correspondence to Dr EJ Duiverman, Department of Paediatrics, Subdivision of Respiratory Disease, Juliana Children's Hospital, Dr van Welylaan 2, 2566 ER The Hague. The Netherlands.

Accepted 19 February 1988 